\title{
Digenea in the Surubim Pseudoplatystoma corruscans (Spix and Agassiz, 1829) (Siluriformes: Pimelodidae) of the Upper São Francisco River, State of Minas Gerais, Brazil
}

\author{
Renata de Fátima da Silva Stravalli Corrêa ${ }^{1 *}$ and Marilia de Carvalho Brasil-Sato ${ }^{2}$ \\ ${ }^{l}$ Estação de Hidrobiologia e Piscicultura; C. P.: 11; refolive@yahoo.com.br; 39205-000; Três Marias - MG - \\ Brasil. ${ }^{2}$ Departamento de Biologia Animal; Universidade Federal Rural do Rio de Janeiro; BR 465; Km. 7; C. P.: \\ 74.539; mcbsato@ufrrj.br; 23851-970; Seropédica - RJ - Brasil
}

\begin{abstract}
The specimens of surubim, Pseudoplatystoma corruscans (Spix and Agassiz, 1829), an important food fish with high commercial value in the Upper São Francisco River, were collected downstream from the Três Marias Dam, in the municipality of Três Marias, State of Minas Gerais, Brazil. Thirty-six individuals were examined and among the parasites, four species of Digenea were found: Witenbergia witenbergi Vaz, 1932 and Tylodelphys sp. (metacercarie), both with prevalence above 10\%, followed by Acanthostomum gnerii (Szidat, 1958) and Acanthostomum sp.. The total length of the hosts did not influence the parasite prevalence. Witenbergia witenbergi occurred only in female hosts and the abundance of Tylodelphys sp. was higher in the males. These Digenea were recorded for the first time in $\mathrm{P}$. corruscans, and their known geographic distribution has been expanded to the São Francisco Basin in Brazil.
\end{abstract}

Key words: Acanthostomum spp., Digenea, Pseudoplatystoma corruscans, São Francisco River Tylodelphys sp., Witenbergia witenbergi

\section{INTRODUCTION}

Pimelodidae include highly diversified types of freshwater fishes with nocturnal habits and varied diets (Britski et al., 1984). Pseudoplatystoma corruscans (Spix and Agassiz, 1829) is an important food fish (Tavares, 1997) that occurs in the Plata and São Francisco basins, where it is known by the popular names of pintado and surubim, respectively (Tavares, 1997, Petrere, 1995). It is a migratory fish (Sato and Godinho, 2003), a carnivore that mainly eats other fish (Sato et al., 1997), and is among the largest fish in the São Francisco basin, reaching more than $100 \mathrm{~kg}$ (Tavares, 1997).

The fishing and biology of $P$. corruscans are well documented (Miranda and Ribeiro, 1997), although few articles are available on its endoparasitic fauna (Machado et al., 1994, 1995, 1996, Brasil-Sato, 2003). In this work we expand the information on the parasites of this host in the São Francisco River, recording for the first time species of Digenea and relating them to the size and sex of the fish. The cultivation of this species

* Author for correspondence 
has been done at the Três Marias Hydrobiology and Fish Farming Station and parasite studies are important for the formation of breeding stocks and maintenance of the healthy hatchlings.

\section{MATERIALS AND METHODS}

The specimens of $P$. corruscans were collected from the Upper São Francisco River $\left(18^{\circ} 12^{\prime} 32^{\prime \prime}\right.$, $45^{\circ} 15^{\prime} 41^{\prime} \mathrm{W}$ ), in the municipality of Três Marias, Minas Gerais, about 500 meters downstream from the Três Marias Dam, from June to September 1999 and June to October 2004, using the round nets. The fishes were identified according to Britski et al. (1984). The total lengths and weights of the eight male specimens were $88.7 \pm 21.9 \mathrm{~cm}$ $(66-125 \mathrm{~cm})$ and $6,763 \pm 6,188 \mathrm{~g}(1,610-17,800 \mathrm{~g})$. The measures for the 28 females were $119.4 \pm 28.5 \mathrm{~cm}(35.5-175 \mathrm{~cm})$ and $16,574 \pm 10,980 \mathrm{~g}$ $(2,400-54,000 \mathrm{~g})$. The parasites were collected and prepared according to Amato et al. (1991) and Eiras et al. (2000). The infrapopulations statistical analysis were according to Zar (1996). Student's $t$ test was used to assess the possible differences in the total length and weight between the males and females and the parasite abundance in relation to the host sex. The Fisher's exact test was carried out to assess the parasite prevalence in relation to the host sex and Pearson's correlation coefficient $(r)$ and Spearman's rank correlation coefficient $\left(r_{s}\right)$ to analyze the possible influence of the host size on the prevalence and parasite abundance, respectively. The significance level was $P<0.05$. The statistical tests for the infrapopulations of the Digenea were applied when the prevalence were above 10\% (Bush et al., 1990), and employed the terminology used by Bush et al. (1997). The voucher specimens were deposited in the Coleção Helmintológica do Instituto Oswaldo Cruz (CHIOC), Rio de Janeiro, Brazil.

\section{RESULTS}

A total of 36 specimens of $P$. corruscans were examined, of which $8(22.22 \%)$ were males and 28 $(77.78 \%)$ were females. The males were smaller $(t=2.774, p=0.009)$ and lighter than the females $(t=2.404, p=0.022)$. Ten individuals $(27.8 \%)$ were parasitized by the Digenea, and were collected 325 specimens: 18 (5.54\%) Witenbergia witenbergi Vaz, 1932, (Opisthorchiidae - CHIOC 36564a-b), $33(10.15 \%)$ Tylodelphys sp. (metacercariae, Diplostomidae - CHIOC 36568, 36569), 252 (77.54\%) Acanthostomum gnerii (Szidat, 1958) (Acanthostomidae - CHIOC 36566a-b, 36567) and $22(6.77 \%)$ Acanthostomum sp. (CHIOC 36565a-b). Eight $P$. corruscans were infected by one species of Digenea (three with $W$. witenbergi, two with Tylodelphys sp., two with A. gneri and one with Acanthostomum sp.), one with two species (Tylodelphys sp.-Acanthostomum sp.) and one with three species (Witenbergia witengergiTylodelphys sp.-Acanthostomum gnerii).

The most prevalent parasites were $W$. witenbergi and Tylodelphys sp., and the highest abundance was of A. gnerii. The parasite indices and place of the infection of the Digenea species in $P$. corruscans are presented in Table 1. The prevalence and abundance of the Digenea were not influenced by the total fish lengths. The abundance of Tylodelphys $s p$. was highest in the male hosts (Table 2) and W. witenbergi occurred only in the female hosts.

Table 1 - Prevalence (P) expressed as a percentage, amplitude of intensity (AI), mean intensity (MI), mean abundance (MA), and place of infection of the parasites of Pseudoplatystoma corruscans (Spix and Agassiz, 1829) from the Upper São Francisco River, Brazil.

\begin{tabular}{lccccc}
\hline Digenea & P(\%) & AI & MI & MA & Place of infection \\
\hline $\begin{array}{l}\text { Witenbergia witenbergi } \\
\begin{array}{l}\text { Tylodelphys sp. } \\
\text { (metacercariae) }\end{array}\end{array}$ & 11.1 & $3-5$ & $4.5 \pm 1.0$ & $0.5 \pm 1.5$ & Middle and posterior intestine \\
$\begin{array}{l}\text { Acanthostomum gnerii } \\
\text { Acanthostomum sp. }\end{array}$ & 11.1 & $1-15$ & $8.2 \pm 5.7$ & $0.9 \pm 3.1$ & $\begin{array}{c}\text { Anterior and middle intestine } \\
\text { and air bladder }\end{array}$ \\
\hline
\end{tabular}


Table 2 - Analysis of the prevalence ( $r$ and $p^{F}$, respectively) and abundance ( $r_{s}$ and $t$, respectively) of the Digenea in relation to total length and sex of Pseudoplatystoma corruscans (Spix and Agassiz, 1829) from the Upper São Francisco River, Brazil.

\begin{tabular}{lccccccc}
\hline \multirow{2}{*}{ Digenea } & \multicolumn{3}{c}{ Total length } & \multicolumn{3}{c}{ Sex } \\
\cline { 2 - 8 } & $\mathbf{r}$ & $\mathbf{p}$ & $\mathbf{r}_{\mathbf{s}}$ & $\mathbf{p}$ & $\mathbf{p}^{\mathbf{F}}$ & $\mathbf{t}$ & $\mathbf{p}$ \\
\hline $\begin{array}{l}\text { Witenbergia witenbergi } \\
\begin{array}{l}\text { Tylodelphys sp. } \\
\text { (metacercariae) }\end{array}\end{array}$ & 0.019 & 0.795 & 0.104 & 0.544 & 0.555 & - & - \\
\hline
\end{tabular}

Pearson's correlation coefficient: $r$; Spearman's rank correlation coefficient: $r_{s}$; Fisher's exact test: $p^{F}$; Student's t test: $t$.

Significance level: $P<0.05$.

\section{DISCUSSION}

The Digenea species found in P. corruscans can enter in these hosts by active or passive transmission. The three Digenea species represented by the adult specimens $(W$. witenbergi, A. gnerii and Acanthostomum sp.) lived their larval stage in winkles, which possibly were eaten by the fish, while the metacercariae of Tylodelphys $s p$. must have actively infected $P$. corruscans. The higher abundance of Tylodelphys sp. in all the male hosts might not have biological significance, considering the type of the transmission of these parasites and the different sample size of the male and female hosts examined in this study. Besides the distribution in the fishes, the finding of these parasites in $P$. corruscans could be very important, because they can will harm the hosts' health. According to Eiras (1994), cercariae penetrated the fishes through any part of their bodies, and metacercariae of Tylodelphys $s p$. have similar behavior as Diplostomum spp., causing formation of cataracts and even death of the fish. Tylodelphys $s p$. were recorded in the brains of Basilichthys microlepidotus (Jennyns, 1841), B. perugiae (Evermann and Kendall) and Austroatherina smitti (Lahille) (=Odonthestes perugiae Evermann and Kendall, 1906 and Odonthestes smitti (Lahille, 1929) according to Dyer (2003)), respectively, coming from the Uruguay River, Plata basin, Argentina (Travassos et al., 1969). These authors indicated the possibility that these metacercariae might extend to Brazilian territory. In this study, the occurrence of Tylodelphys sp. in Brazil has been demonstrated, and in a new intermediate host, since it matured in the gut of fish-eating birds.

These parasites can act in the structure of the host communities and can be important in modeling the parasite communities (Poulin, 1999). The values of the parasite indices indicate the importance of this group of parasites in the composition and structure of the parasite community of $P$. corruscans in the Upper São Francisco, although there are few reports of Digenea in these fishes in other watersheds. Witenbergia witenbergi was recorded in $P$. tigrinum (Valenciennes, 1840) from the Amazon basin (Travassos et al., 1969). In $P$. corruscans from the Paraná River, Clinostomum marginatum (immature form) was found in the stomach (Fernandes and Kohn, 2001). Because of its habit of eating arthropods, and other fishes, other species of helminths are favored in its parasite fauna. This sheds light on why cestodes and nematodes occur in the parasite fauna of $P$. corruscans in the Paraná River, with predominance of cestodes (Machado et al., 1994), and the various reports of cestodes species in $P$. corruscans and in similar hosts in South America (Rego and Pavanelli, 1992). While necropsying the $P$. corruscans, some nematodes were also found, but in the quantitative results of the parasite community, the cestodes continued to be the dominant parasite group in this host.

The fact that $W$. witenbergi was found only in the females might indicate the diet selection in these fishes, although this result could have been purely accidental in the studied sample or influenced by the higher number of the females examined. Acanthostomum gnerii is cited as occurring in Rhamdia quelen (Quoy and Gaimard, 1824) (Travassos et al., 1969) and in R. quelen and $R$. rogersi Regan, 1907 - junior synonym of $R$. laticauda (Kner, 1857) according to Dyer (2003) in Costa Rica and Argentina (Thatcher, 1993). Other similar parasites have been cited in the reptiles by these authors. The higher number of spines $(n=27-28)$ on the anterior extremity of Acanthostomum sp. of $P$. corruscans from the São Francisco River sets it apart from the taxa recorded in the hosts in Brazil. Hence, there is a need to intensify taxonomic research in this group. 
Muzall and Bullock (1980) highlighted the direct variation of the endoparasite fauna of the fishes with their access to different food items during the migration, which could be the case of the surubims in the São Francisco, with their parasite fauna varying by accumulating the parasites from more preferred and/or available food items during their migratory travels.

In this study, W. witenbergi, Tylodelphys sp., Acanthostomum gnerii and Acanthostomum sp. were recorded in $P$. corruscans for the first time and the known geographic distribution of this species were expanded to the drainage basin of the São Francisco River in Brazil.

\section{ACKNOWLEDGMENTS}

We would like to thank Dr. Yoshimi Sato, Head of the Hydrobiology and Fish Farming Station of CODEVASF for help in collecting the fish and while carrying out this study, and the CEMIG GT/CODEVASF and UFRRJ/IBAMA working agreements for logistical and material support.

\section{RESUMO}

Espécimes de surubim, Pseudoplatystoma corruscans (Spix e Agassiz, 1829), importante peixe na pesca profissional e de maior valor comercial, do Alto Rio São Francisco, foram coletados à jusante da barragem de Três Marias, município de Três Marias, Minas Gerais. Foram examinados 36 indivíduos e dentre outros parasitos, foram encontradas quatro espécies de Digenea: Witenbergia witenbergi Vaz, 1932 e Tylodelphys sp. (metacercárias) ambas com prevalência superior a $10 \%$, seguidas por Acanthostomum gnerii (Szidat, 1958) e Acanthostomum sp.. O comprimento total dos hospedeiros não influenciou a prevalência e a abundância parasitária. Witenbergia witenbergi ocorreu apenas em hospedeiros fêmeas e a abundância de Tylodelphys sp. foi mais elevada nos hospedeiros machos. Esses Digenea foram registrados pela primeira vez em $P$. corruscans e tiveram sua distribuição geográfica conhecida ampliada para a bacia do São Francisco, Brasil.

\section{REFERENCES}

Amato, J. F. R.; Boeger, W. A. and Amato, S. B. (1991), Protocolos para laboratório-coleta $e$ processamento de parasitos do pescado. Imprensa Universitária, Universidade Federal Rural do Rio de Janeiro, Rio de Janeiro.

Brasil-Sato, M. C. (2003), Parasitos de peixes da bacia do São Francisco. In: Águas, peixes e pescadores do São Francisco das Minas Gerais. H. P. Godinho and A.L. Godinho (Org.). PUC Minas, Belo Horizonte, pp.149-165.

Britski, H. A.; Sato, Y. and Rosa, A. B. S. (1984), Manual de identificação de peixes da região de Três Marias (com chave de identificação para peixes da bacia do rio São Francisco). CODEVASF, Brasília.

Bush, A. O.; Aho, J. M. and Kennedy, C. R. (1990), Ecological versus Phylogenetic determinants of helminth parasite community richness. Evolut. Ecol., 4, 1-20.

Bush, O. A.; Lafferty, K. D.; Lotz, J. M. and Shostak, A. W. (1997), Parasitology meets ecology on its own terms: Margolis et al. Revisited. J. Parasitol., 83, 575-583.

Dyer, B. S. (2003), Family Atherinopsidae (Neotropical silversides). In: Reis, R. E.; Kullander, S. O. and Ferraris JR, C. J. Check List of the Freshwater Fishes of South and Central America. EDIPUCRS, Porto Alegre, pp. 515-525.

Eiras, J. C. (1994), Elementos de Ictioparasitologia. Fundação Eng. Antônio de Almeida, Porto.

Eiras, J. C.; Takemoto, R. M. and Pavanelli, G. C. (2000), Métodos de estudo e técnicas laboratoriais em parasitologia de peixes. EDUEM, Maringá.

Fernandes, B. M. M. and Kohn, A. (2001), On some trematodes parasites of fishes from Paraná river. Braz. J. Biol., 61, 461-466.

Machado, M. H.; PavanellI, G. C. and Takemoto, R. M. (1994), Influence of host's sex and size on endoparasitic infrapopulations of Pseudoplatystoma corruscans and Schizodon borelli (Osteichthyes) of the high Paraná river, Brazil. Rev. Bras. Parasit. Vet., 3, 143-148.

Machado, M. H.; Pavanelli, G.C. and Takemoto, R. M. (1995), Influence of the type of environment and the hydrological level variation in endoparasitic infrapopulations of Pseudoplatystoma corruscans (Agassiz) and Schizodon borelli (Boulenger) (Osteichthyes) of the high Paraná River, Brazil. Rev. Bras. Zoo., 12, 961-976. 
Machado, M. H.; Pavanelli, G. C. and Takemoto, R. M. (1996), Structure and diversity of endoparasitic infracommunities and the trophic level of Pseudoplatystoma corruscans and Schizodon borelli (Osteichthyes) of the high Paraná river. Mem. Inst. Oswaldo Cruz, 91, 441-448.

Miranda, M. O. T. and Ribeiro, L. P. (1997), Características zootécnicas do surubim Pseudoplatystoma coruscans. In: Miranda M. O. T. (Org.) Surubim (Coleção Meio Ambiente, Série Estudos: Pesca, n. 19). Belo Horizonte: IBAMA, pp. 43-56

Muzall, P. M. and Bullock, W. L. (1980), Seasonal occurrence and host parasite relationships of Neochinorhynchus saginatus Wan Cleaver and Banghm, 1949 in the fallfish, Cemotilus corporalis (Mitchill). J. Parasit., 55, 1212-1217.

Petrere Jr., M. (1995), A pesca de água doce no Brasil. Ciência Hoje, 19, 28-33.

Poulin, R. (1999), The functional importance of parasites in animal communities: many roles at many levels? Int. J. Parasit., 29, 903-914.

Rego, A. A. and Pavanelli, G. C. (1992), Checklist of the cestode order Proteocephalidea parasites from South América freshwater fishes. Rev. UNIMAR, 14, 109-137.
Sato, Y.; Cardoso, E. L.; Sallum, W. B. and Godinho, H. P. (1997), Indução experimental da desova do Surubim Pseudoplatystoma corruscans. In: Miranda M. O. T. (Org.) Surubim (Coleção Meio Ambiente, Série Estudos: Pesca, n. 19). Belo Horizonte: IBAMA, pp. 69-79.

Sato, Y. and Godinho, H. P. (2003), Migratory Fishes of the São Francisco River. In: Migratory Fishes of South America. Biology, Fisheries and Conservation Status. Carolsfeld, J; Harvey, B.; Ross, C. and Baer, A. (eds). IDRC/World Bank, Victoria, pp. 195-232.

Tavares, M. P. O. (1997), O Surubim. In: Surubim (Coleção Meio Ambiente, Série Estudos: Pesca, 19). Miranda, M. O. T. (Org.). Belo Horizonte: IBAMA, pp. 9-25.

Thatcher, V. E. (1993), Trematódeos Neotropicais. INPA, Manaus.

Travassos, L., Freitas, J. F. T. and Kohn, A. (1969), Trematódeos do Brasil. Mem. Inst. Oswaldo cruz, 76, 1-886.

Zar, J. H. (1996), Biostatistical Analysis. $3^{\text {rd }}$ ed. Prentice-Hall, Inc., New Jersey.

Received: November 25, 2006; Revised: October 17, 2007; Accepted: March 12, 2008. 


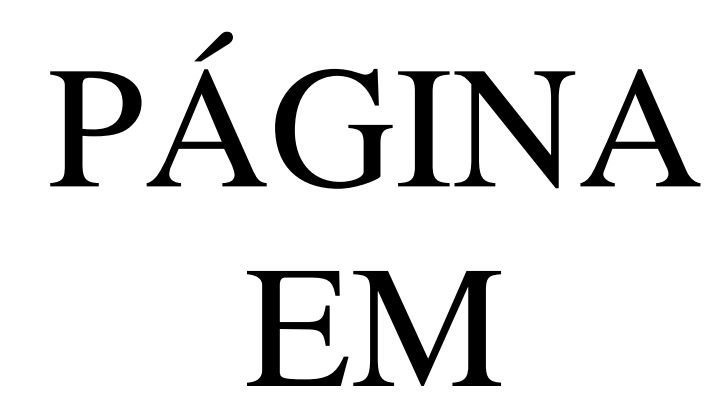

BRANCO 